\title{
INFORMING FUTURE LEARNING DESIGNS IN PRESERVICE TEACHER EDUCATION THROUGH QUANTITATIVE RESEARCH: A PRIMARY SCIENCE EXAMPLE
}

\author{
Peter Hudson \\ Centre for Learning Innovation \\ Queensland University of Technology, AUSTRALIA \\ pb.hudson@qut.edu.au
}

\begin{abstract}
Reform documents have provided a framework for advancing science education (e.g., The Australian National Science Standard Committee, 2002), but omit the need to assess preservice teachers' prior knowledge for designing effective learning programs. A pretest-posttest 34-item survey linked to the course outcomes (associated with four constructs) measured 66 third-year preservice teachers' perceptions towards becoming primary science teachers. Effect sizes were educationally and statistically significant for each of the four constructs (i.e., Theory [d=1.08], Children's Development [d=1.60], Planning [d=1.17], Implementation [d=0.89]. Paired t-tests were also significant for the first three constructs; however posttest results revealed less than $90 \%$ of these participants disagreed or strongly disagreed with 4 of the 14 items associated with the fourth construct (i.e., Implementation). The results implied that the learning design for this course requires revision in areas where indicators were shown to be not significant. A pretest-posttest survey can aid in identifying preservice teachers' prior knowledge for advancing tertiary coursework by catering for the learners' needs.
\end{abstract}

Keywords

pedagogical knowledge, science education, preservice teachers, tertiary coursework

\section{Agendas for Developing Preservice Teachers}

The quality of science education has been identified as an international problem (e.g., Bybee, \& McInerney, 1995; Goodrum, Hackling, \& Rennie, 2001; Lunetta \& Lederman, 1998). Many reform agendas have been implemented to address the inadequacies of science education in primary schools and assist the facilitation of such education (Harlen, 1999; Jarvis, McKeon, Coates, \& Vause, 2001; Hudson \& McRobbie, 2004). Despite these efforts, the quality of science education requires considerable development in Australia (Goodrum et al., 2001). However, preservice teachers are generally interested in developing pedagogical practices in science education (Rice \& Roychoudhury, 2003). Hence, a way forward for advancing science education reform processes must include preservice teacher education (Watters \& Ginns, 2000).

The Australian National Science Standard Committee (ANSSC, 2002) and the American Association for the Advancement of Science (AAAS, 1993) advocate the development of preservice teachers' pedagogical knowledge as a way for implementing current science education practices. Universities involved in preservice teacher education also aim to advance science education by designing 
coursework based on current theories and practices for teaching science education. The development of preservice teachers' skills for teaching science requires scaffolding with focused attention on the acquisition of pedagogical knowledge (Abell \& Bryan, 1999; Briscoe \& Peters, 1997; Coates, Jarvis, McKeon, \& Vause, 1998; Hudson, Skamp, \& Brooks, 2005), which facilitates students' learning of science concepts.

Pedagogical knowledge for educating preservice primary science teachers includes understanding:

1. theoretical underpinnings used for developing a science curriculum.

2. the development of children's science concepts, scientific reasoning abilities, manipulative skills, and attitudes.

3. effective planning for science teaching and learning.

4. the implementation of effective science teaching practices, including successful management of the learning environment.

To be adequately prepared for primary science teaching, preservice teachers need to analyse and understand current theories that underpin a science curriculum (Fleer \& Hardy, 2001). Constructivism is one such theory advocated for primary science teaching as it promotes hands-on learning with consideration of prior knowledge and students' misconceptions (Skamp, 2004). The development of a science syllabus generally draws upon current theories (e.g., Board of Studies, 1999; Queensland School Curriculum Council, 1999), hence, preservice teachers need an understanding of current theories and make the connections to practice as advocated by the presiding syllabus.

National reform agendas (ANSSC, 2002; AAAS, 1993) advocate inquiry-based learning with equal opportunities for all students to develop scientific literacy. This requires preservice teachers to understand students' prior knowledge (Skamp, 2004), misconceptions or alternative conceptions (Wandersee, Mintzes, \& Novak, 1994) and manipulative skills and attitudes (Fleer \& Hardy, 2001) in order to facilitate appropriate and relevant science lessons (Abruscato, 2004). Preservice teachers need to have a repertoire of primary science teaching approaches (e.g., inquiry, interactive, and discovery approaches; see Fleer \& Hardy, 2001) and successful science teaching models (e.g., Bybee's Five Es [1997] and Gunstone and White's [1981] predict-observe-explain [POE] model). “Articulating viewpoints about theories, approaches, and models for teaching science may demonstrate a preservice teacher's propensity for developing effective primary science education lessons" (Hudson \& Ginns, 2005).

Preservice teachers planning for facilitating effective science education is paramount (Jarvis et al., 2001), which involves understanding key components of a science education program. A theoretically based rationale for teaching science, a scope and sequence for providing long-term science topics, integrating science with other key learning areas (Hudson, 2000), and the use of concept maps that provide visual connections to other key learning areas (Fleer \& Hardy, 2001) aid in the planning process. In addition, outcomes-based education for planning, implementing, and assessing primary science education provides a stronger focus on students' achievements (e.g., AAAS, 1993; Board of Studies, 1999; Queensland School Curriculum Council, 1999). This involves developing in preservice teachers appropriate teaching strategies (Tobin \& Fraser, 1990), preparation of resources (Rosaen \& Lindquist, 1992), classroom management strategies (Feiman-Nemser \& Parker, 1992), questioning techniques (Fleer \& Hardy, 2001), content knowledge (Skamp, 2004), and effective assessment and evaluation procedures (Corcoran \& Andrew, 1988; Jarvis et al., 2001). Preservice teachers also need to develop critical self-reflection in order to enhance their pedagogical practices (Schön, 1987). Addressing ethical and attitudinal issues can also aim at catering for all students regardless of ability (AAAS, 1993; Fleer \& Hardy, 2001). 


\section{Scope and Sequence for this Study's Science Education Curriculum}

Preservice teachers involved in this study completed a science pedagogy course of one-semester duration. The course structure involved a one-hour lecture, a one-hour tutorial, and a two-hour workshop each week. Lecture topics included: Constructivism; The social nature of learning; Conceptual change; Problem-based inquiry; Instructional designs; and Designing units of work. Fundamental to tertiary education is placing the preservice teacher at the centre of learning, which requires high levels of individual responsibility (e.g., Sparrow, Sparrow, \& Swan, 2000). The inclusion of workshops and tutorials provided opportunities for peer collaboration, which can enhance the learning environment (Biggs, 1999). After three weeks of tutor-demonstrated science lessons, pairs of preservice teachers presented primary science lessons to their peers in subsequent workshops. The lesson presentations aimed at providing preservice teachers with first-hand teaching experiences with feedback from their tutor and peers. It was intended that preservice teachers would benefit from the experience of teaching science to their peers. Tutorials aimed to assist the preservice teachers develop a detailed primary science unit of work. The lesson presentation with related documentation (including a critical self reflection) and the science unit of work were assessable items in the course, and were key influences upon the preservice teachers' learning. Online material further supported the preservice teachers' learning with course materials, relevant readings, and examples for completing various assessment tasks. Table 1 provides the scope and sequence of the curriculum used to educate the preservice teachers in this particular tertiary education course.

Table 1: Scope and sequence: Lectures, tutorials, and workshops

\begin{tabular}{|l|l|l|}
\hline Lecture (1 hour) & Tutorial (1 hour) & Workshop (2 hours) \\
\hline $\begin{array}{l}\text { Defining science; working } \\
\text { scientifically }\end{array}$ & $\begin{array}{l}\text { Prior understandings of } \\
\text { science teaching; science in } \\
\text { the community }\end{array}$ & Hands-on science activities \\
\hline $\begin{array}{l}\text { Theories and approaches for } \\
\text { learning and teaching in } \\
\text { science education }\end{array}$ & $\begin{array}{l}\text { Prior knowledge, } \\
\text { misconceptions, and science } \\
\text { teaching approaches }\end{array}$ & Hands-on science activities \\
\hline $\begin{array}{l}\text { The science syllabus and } \\
\text { constructing a curriculum }\end{array}$ & $\begin{array}{l}\text { Investigating the state science } \\
\text { syllabus }\end{array}$ & Hands-on science activities \\
\hline $\begin{array}{l}\text { Planning a science unit of } \\
\text { work, and the importance of } \\
\text { content knowledge and } \\
\text { pedagogical knowledge }\end{array}$ & $\begin{array}{l}\text { Content knowledge and } \\
\text { pedagogical knowledge for } \\
\text { science education }\end{array}$ & $\begin{array}{l}\text { Pairs of preservice teachers } \\
\text { presenting science lessons to } \\
\text { peers; constructing critical } \\
\text { self-reflection }\end{array}$ \\
\hline $\begin{array}{l}\text { Programming for science: } \\
\text { syllabus, policy, rationale, } \\
\text { scope and sequence, unit } \\
\text { overview, and integrated } \\
\text { overview }\end{array}$ & $\begin{array}{l}\text { Constructing science } \\
\text { education overviews, and } \\
\text { scope and sequences }\end{array}$ & $\begin{array}{l}\text { Pairs presenting science } \\
\text { lessons to peers; } \\
\text { constructing critical self- } \\
\text { reflection }\end{array}$ \\
\hline $\begin{array}{l}\text { Devising science lessons and } \\
\text { managing the learning } \\
\text { environment (including } \\
\text { classroom management and } \\
\text { resource management) }\end{array}$ & $\begin{array}{l}\text { Ways of managing the } \\
\text { learning environment for } \\
\text { science education }\end{array}$ & $\begin{array}{l}\text { Pairs presenting science } \\
\text { lessons to peers; critical self- } \\
\text { reflection }\end{array}$ \\
\hline $\begin{array}{l}\text { Assessment, evaluation, and } \\
\text { reporting in science education }\end{array}$ & $\begin{array}{l}\text { Techniques and formats for } \\
\text { assessment, evaluation, and } \\
\text { reporting science education }\end{array}$ & $\begin{array}{l}\text { Pairs presenting science } \\
\text { lessons to peers; critical self- } \\
\text { reflection }\end{array}$ \\
\hline $\begin{array}{l}\text { Professional development and } \\
\text { involvement in schools for } \\
\text { enhancing science education }\end{array}$ & $\begin{array}{l}\text { Devising future professional } \\
\text { education }\end{array}$ & $\begin{array}{l}\text { Pairs presenting science } \\
\text { lessons to peers; critical self- } \\
\text { reflection }\end{array}$ \\
\hline
\end{tabular}




\section{Study Aim}

In order to determine the extent of achieving fundamental elements for implementing science education reform, educators at universities need to understand preservice teachers' stage of development. Specifically, assessments of preservice teachers' prior knowledge of primary science teaching practices can provide information for educators to design more effective learning programs. Identifying preservice teachers' strengths and weaknesses for teaching science may enable science educators to target learning needs and by comparing prior knowledge with posttest assessment may determine the extent of achieving education reforms. Hence, this study aimed to assess preservice teachers' knowledge for teaching primary science before and after involvement in a science pedagogy course that may be associated with reform directions.

\section{Data collection methods and analysis}

A pretest-posttest survey instrument was used to assess 66 third-year preservice teachers' primary science pedagogical development at the conclusion of a science pedagogy course at one Australian university. Pretest-posttest data provided a means for analysing changes that have occurred (Hittleman \& Simon, 2002). Survey responses with missing or improbable values were deleted (Hittleman \& Simon, 2002); hence the initial 83 returned surveys were reduced to 66. This sample $(n=66)$ represented $38 \%$ of the total cohort of third-year perservice teachers. The 34 survey items had a five-part Likert scale, namely, "strongly disagree", "disagree", "uncertain", "agree", and "strongly agree". Scoring was accomplished by assigning a score of one to items receiving a "strongly disagree" response, a score of two for "disagree" and so on through the five response categories.

The statements on the survey sought participants' perceptions of their development towards becoming primary science teachers. The items on the survey appeared to represent relevant indicators of four course outcomes (constructs), which are also within the literature (e.g., Fleer \& Hardy, 2001; Skamp, 2004). These items were used to form a scale for each construct. For example, the course outcome "understands theoretical underpinnings used for developing a science curriculum", identified in subsequent discussion as the construct Theory, was linked to the following indicators on the survey: articulate the key components of the science syllabus; provide a rationale based on theory for designing and implementing an effective science program; describe and analyse the theoretical base of science curriculum development; articulate constructivist principles for teaching science; compare existing approaches for teaching science; articulate different viewpoints on teaching science; and, talk comfortably about teaching science. The remaining constructs were identified as follows: Children's Development (Understanding of the development of children's concepts, abilities, skills, and attitudes); Planning (Understanding effective planning for science teaching and learning); and Implementation (Implementing effective science teaching practices). To further substantiate the author-designed instrument's validity, four primary science teacher educators examined the items on the survey.

Descriptive statistics were derived using SPSS13. Data analysis included: frequencies of each survey item under each associated construct (outcome), mean scores $(M)$, and standard deviations ( $S D$, see Hittleman \& Simon, 2002). The $M$ and $S D$ were used to calculate $t$-tests "to determine whether the difference between the means of two [samples] on a dependent variable is significant" (Hittleman \& Simon, 2002, p. 36). The effect size $(d)$ of the difference in mean scores over the total $S D$ (Kline, 1998) was calculated between the pretest and posttest on each of the four hypothesised constructs (i.e., Theory, Children's Development, Planning, and Implementation). In educational contexts, "effect sizes of .20 are considered small; .50, medium; and, .80, large” (Hittleman \& Simon, 2002, p. 178). Analysing individual items aimed to provide further insight into these constructs. 


\section{Results and discussion}

The following are key descriptors of the participants ( $n=66 ; 51$ female, 15 male) provided from the preservice teachers' responses on the first section of this survey (Appendix 1). Although $42 \%$ of these preservice teachers were less than 22 years of age and $30 \%$ were between 22 and 29 years of age, there were also $28 \%$ who were older than 30 years of age. Sixty-five percent of the preservice teachers completed science content courses in Grades 11 and 12 at high school. Fifty-three percent had completed one science and mathematics content course, and $47 \%$ had completed two or more courses. In addition, posttest data revealed $15 \%$ completed one practicum (field experience) and $85 \%$ indicated they had completed more than one practicum. Eighty-nine percent claimed they had taught at least one science lesson in their field experiences. Comparison between pretest and posttest responses indicated that there was no change for preservice teachers wanting to learn about teaching primary science in other educational systems (pretest $=74 \%$, posttest $=74 \%$ ), however, there was an $11 \%$ increase wanting to collaborate with university teacher education students from other countries (pretest $=47 \%$, posttest $=58 \%$ ). Fifty-two percent indicated that science may be considered a strength at the conclusion of this course (compared with $38 \%$ in the pretest) and there was only an increase of $12 \%$ for those who believed they had the knowledge and skills in primary science teaching to interact effectively with university teacher education students from other countries (pretest $=49 \%$, posttest=61\%).

\section{Effect sizes and descriptive statistics for the four constructs}

Effect sizes were educationally and statistically significant for each of the four constructs (i.e., Theory [ $d=1.08]$, Children's Development [ $d=1.60]$, Planning [ $d=1.17]$, Implementation $[d=0.89] ; p<.001$, Table 2). Mean scale scores were considerably higher for the posttest, which also had significantly lower $S D$ on each of the four constructs indicating less variance in the posttest responses (Table 2).

Table 2: Descriptive Statistic and Effect Sizes for the Four Constructs for Preservice Teachers'

\begin{tabular}{|c|c|c|c|c|c|c|}
\hline \multirow[b]{2}{*}{ Construct } & \multicolumn{2}{|c|}{ Pretest } & \multicolumn{2}{|c|}{ Posttest } & \multirow{2}{*}{$\begin{array}{c}\text { Mean } \\
\text { score } \\
\text { differences }\end{array}$} & \multirow{2}{*}{$\begin{array}{c}\text { Effect } \\
\text { size* }^{*}\end{array}$} \\
\hline & $M$ & $S D$ & $M$ & $S D$ & & \\
\hline Theory & 3.50 & 0.60 & 4.07 & 0.32 & 0.43 & 1.08 \\
\hline Children's Development & 3.38 & 0.60 & 4.02 & 0.36 & 0.64 & 1.60 \\
\hline Planning & 3.79 & 0.48 & 4.20 & 0.34 & 0.41 & 1.17 \\
\hline Implementation & 3.81 & 0.46 & 4.12 & 0.35 & 0.31 & 0.89 \\
\hline
\end{tabular}

\section{Understanding the Theory for Developing a Science Curriculum (Construct - Theory)}

Results from $t$-tests for the first construct, understanding the theoretical underpinnings used for developing a science curriculum (Theory), were significant $(p<.001)$ with a range between -4.72 to 12.69 (Table 3). The posttest results further indicated that more than $85 \%$ of these preservice teachers generally agreed or strongly agreed that they believed they understood the Theory used for developing a primary science curriculum. Percentages of preservice teachers who responded agree and strongly agree for each associated indicator in the pre and posttests are shown in Table 3. Of interest was the significant percentage increase in the preservice teachers' perceptions for the indicators: describe and analyse the theoretical base of science curriculum development (Item 9: pretest $=26 \%$, posttest=100\%); and articulate different viewpoints on teaching primary science (Item 23: pretest $=44 \%$, posttest $=97 \%$ ). The second assessment task had criteria associated with these two items, which meant that the preservice teachers needed to have clear understandings of these concepts as a course requirement. 
Table 3: Descriptive Statistics and ANOVA of Preservice Teachers' (n=66) Pretest-Posttest Responses for the Construct "Theory"

\begin{tabular}{|c|c|c|c|c|c|c|c|c|}
\hline \multirow[b]{2}{*}{ Item } & \multirow[b]{2}{*}{ Indicator } & \multicolumn{3}{|c|}{ Pretest } & \multicolumn{3}{|c|}{ Posttest } & \multirow{2}{*}{$\begin{array}{l}\text { Paired } t \\
\text { test }\end{array}$} \\
\hline & & $M$ & $S D$ & $\% *$ & $M$ & $S D$ & $\% *$ & \\
\hline 1 & Syllabus & 3.45 & 1.00 & 64 & 4.06 & 0.55 & 95 & -5.23 \\
\hline 3 & Rationale & 3.42 & 0.84 & 56 & 3.98 & 0.57 & 86 & -5.40 \\
\hline 9 & Theory & 3.05 & 0.79 & 26 & 4.43 & 0.50 & 100 & -12.69 \\
\hline 15 & Constructivist & 3.58 & 0.79 & 54 & 4.09 & 0.65 & 89 & -5.75 \\
\hline 18 & Teaching approaches & 3.61 & 0.76 & 62 & 4.29 & 0.40 & 99 & -4.72 \\
\hline 23 & Viewpoints & 3.33 & 0.75 & 44 & 4.22 & 0.48 & 97 & -7.92 \\
\hline 33 & Talking about science & 3.58 & 0.81 & 64 & 4.23 & 0.67 & 95 & -5.25 \\
\hline
\end{tabular}

* Percentage of preservice teachers who "agreed" or "strongly agreed" that they believed they understood the theory for developing a science curriculum; $* * p<.001$

\section{Understanding of the Development of Children's Concepts, Abilities, Skills, and Attitudes (Construct - Children's Development)}

The second construct examined was the preservice teachers' understanding of the development of children's science concepts, scientific reasoning abilities, manipulative skills, and attitudes (Children's Development). Differences in pretest-posttest responses indicated increases in the mean scores reflected in the $t$-tests (range: -2.72 to $-4.50 ; p<.01$ ) with a smaller variation in the $S D$ for the posttest (Table 4). Descriptive statistics revealed that more than $20 \%$ of these preservice teachers neither agreed nor strongly agreed they understood the development of children's science concepts, manipulative skills, and attitudes at the conclusion of this course (Table 4).

Table 4: Descriptive Statistics and ANOVA of Preservice Teachers' ( $\mathrm{n}=66$ ) Pretest-Posttest Responses for the Construct "Children's Development"

\begin{tabular}{|c|c|c|c|c|c|c|c|c|}
\hline \multirow[t]{2}{*}{ Item } & \multirow[t]{2}{*}{ Indicator } & \multicolumn{3}{|c|}{ Pretest } & \multicolumn{3}{|c|}{ Posttest } & \multirow{2}{*}{$\begin{array}{c}\text { Paired } t \\
\text { test } * *\end{array}$} \\
\hline & & $M$ & $S D$ & $\% *$ & $M$ & $S D$ & $\% *$ & \\
\hline 2 & Scientific reasoning & 3.39 & 0.86 & 53 & 3.84 & 0.50 & 79 & -4.28 \\
\hline 6 & Attitudes & 3.66 & 0.71 & 68 & 4.09 & 0.56 & 88 & -4.50 \\
\hline 17 & Science concepts & 3.53 & 0.78 & 59 & 3.98 & 0.51 & 86 & -4.57 \\
\hline 28 & Manipulative skills & 3.41 & 0.72 & 45 & 3.68 & 0.61 & 70 & -2.72 \\
\hline
\end{tabular}

\section{Understanding Effective Planning for Science Teaching and Learning (Construct - Planning)}

The third construct examined preservice teachers' understandings for effective planning for science teaching and learning. Pretest-posttest responses indicated significant increases in the mean scores with smaller variation in the $S D$ for the posttest, and significant $t$-tests (range: -2.99 to $-6.83, p<.01$ ) for the associated indicators (Table 5). Posttest statistics indicated that more than $90 \%$ of these preservice teachers agreed or strongly agreed that they could devise clear lesson plans for teaching science (Item 5), devise a scope and sequence (Item 7), integrate science across the curriculum (Item 14), select appropriate science activities (Item 19), and develop concept maps for planning a primary science unit of work (Item 29). Analysis of percentages also indicated a posttest increase in understanding inclusive science education (Item 26: pretest $=70 \%$, posttest $=89 \%$ ), developing a science program (Item 8: pretest $=50 \%$, posttest $=88 \%$ ), and articulating the affective domains for teaching and learning primary science $($ Item 12: pretest $=39 \%$, posttest $=86 \%$; Table 5). 
Table 5: Descriptive Statistics and ANOVA of Preservice Teachers' (n=66) Pretest-Posttest Responses for the Construct "Planning"

\begin{tabular}{|c|c|c|c|c|c|c|c|c|}
\hline \multirow[t]{2}{*}{ Item } & \multirow[t]{2}{*}{ Indicator } & \multicolumn{3}{|c|}{ Pretest } & \multicolumn{3}{|c|}{ Posttest } & \multirow{2}{*}{$\begin{array}{l}\text { Paired } \\
t \text {-test*** }\end{array}$} \\
\hline & & $M$ & $S D$ & $\% *$ & $M$ & $S D$ & $\% *$ & \\
\hline 5 & Lesson plans & 3.97 & 0.52 & 88 & 4.35 & 0.54 & 97 & -5.12 \\
\hline 7 & Scope and sequence & 3.50 & 0.75 & 53 & 4.13 & 0.60 & 91 & -6.34 \\
\hline 8 & Program & 3.44 & 0.75 & 50 & 4.00 & 0.50 & 88 & -6.27 \\
\hline 10 & Outcomes & 3.94 & 0.63 & 86 & 4.31 & 0.50 & 99 & -4.73 \\
\hline 12 & Affective domain & 3.32 & 0.75 & 39 & 3.95 & 0.48 & 86 & -6.83 \\
\hline 14 & Integrate & 4.12 & 0.62 & 89 & 4.41 & 0.55 & 97 & -3.36 \\
\hline 19 & Appropriate activities & 3.60 & 0.76 & 62 & 4.26 & 0.56 & 95 & -4.42 \\
\hline 26 & Inclusivity & 3.76 & 0.67 & 70 & 4.06 & 0.52 & 89 & -2.99 \\
\hline 29 & Concept map & 3.71 & 0.92 & 73 & 4.31 & 0.56 & 98 & -4.90 \\
\hline
\end{tabular}

* Percentage of preservice teachers who "agreed" or "strongly agreed" that they believed they understood effective planning for science teaching and learning; $* * p<.01$

\section{Implementing Effective Science Teaching Practices (Construct - Implementation)}

Finally, the fourth construct involved an examination of preservice teachers' understandings of implementing effective science teaching practices, including successful management of the learning environment. Pretest results indicated that third-year preservice teachers had some understanding of implementing primary science education (range: 52-92\%) before commencing this science education course. However, $t$-tests were not significant (range: 1.46 to -6.00) for six Implementation items (i.e., items 13, 20, 22, 25, 27, \& 31; Table 6).

Table 6: Descriptive Statistics and ANOVA of Preservice Teachers' ( $\mathrm{n}=66)$ Pretest-Posttest Responses for the Construct "Implementation"

\begin{tabular}{|c|c|c|c|c|c|c|c|c|}
\hline \multirow[t]{2}{*}{ Item } & \multirow[t]{2}{*}{ Indicator } & \multicolumn{3}{|c|}{ Pretest } & \multicolumn{3}{|c|}{ Posttest } & \multirow{2}{*}{$\begin{array}{c}\text { Paired } t \text { - } \\
\text { test }\end{array}$} \\
\hline & & $M$ & $S D$ & $\% *$ & $M$ & $S D$ & $\% *$ & \\
\hline 4 & Problem-based learning & 3.80 & 0.61 & 73 & 4.20 & 0.57 & 93 & $-4.60 * *$ \\
\hline 11 & Strategies & 3.68 & 0.61 & 67 & 4.15 & 0.47 & 95 & $-5.58 * *$ \\
\hline 13 & Classroom management & 3.97 & 0.50 & 89 & 4.15 & 0.53 & 92 & $-2.34 * * *$ \\
\hline 16 & Learning environment & 3.86 & 0.59 & 79 & 4.10 & 0.46 & 94 & $-2.80 * *$ \\
\hline 20 & Ethical issues & 3.71 & 0.67 & 68 & 3.97 & 0.55 & 81 & $-2.42 * * *$ \\
\hline 21 & Unit of work & 3.80 & 0.77 & 76 & 4.18 & 0.44 & 98 & $-4.05 * *$ \\
\hline 22 & Assessments & 3.90 & 0.57 & 82 & 3.88 & 0.51 & 83 & $0.39 * * *$ \\
\hline 24 & Critical reflection & 3.82 & 0.70 & 77 & 4.26 & 0.54 & 95 & $-4.55^{* *}$ \\
\hline 25 & Questioning skills & 3.88 & 0.64 & 82 & 4.06 & 0.55 & 88 & $-1.99 * * *$ \\
\hline 27 & Evaluate & 3.86 & 0.65 & 80 & 3.71 & 0.60 & 77 & $1.46^{* * *}$ \\
\hline 30 & Positive attitudes & 4.03 & 0.58 & 91 & 4.27 & 0.51 & 97 & $-4.16 * *$ \\
\hline 31 & Hands-on lessons & 3.05 & 0.54 & 92 & 4.12 & 0.48 & 94 & $-0.62 * * *$ \\
\hline 32 & Content knowledge & 3.45 & 0.86 & 52 & 4.15 & 0.56 & 91 & $-6.00 * *$ \\
\hline 34 & Teaching confidently & 3.55 & 0.80 & 62 & 4.22 & 0.67 & 95 & $-5.85^{* *}$ \\
\hline
\end{tabular}

Nevertheless, posttest results revealed that more than $90 \%$ of third-year preservice teachers agreed or strongly agreed with 10 of the 14 items (Table 6). Posttest percentages increased for all items, except for critically evaluating their primary science teaching (Item 22), which showed a $3 \%$ decrease. It may be that these preservice teachers were overly confident in their concepts of evaluating primary science teaching practices before commencing the course. 


\section{Conclusion}

The findings of this study indicated that the majority of these preservice teachers perceived they had developed pedagogical understandings for science education on each of the four constructs (i.e., Theory, Children's Development, Planning, and Implementation). Indeed, significant effect sizes may be expected after preservice teacher involvement in a science pedagogical course, however, not expected were non-significant $t$-tests for 6 of the 34 indicators (items 13, 20, 22, 25, 27, 31). All of these items were associated with the construct Implementation. As percentages were high for the posttest results for this construct, it implies that these preservice teachers had more understanding of implementing primary science teaching practices than the other three constructs. There was very little movement between some of the pretest and posttest items within this construct (e.g., hands-on experiences; pretest $=92 \%$, posttest $=95 \%$ ), which may result in non-significant $t$-tests. Nevertheless, $30 \%$ of these preservice teachers believed they did not have an understanding of children's manipulative skills for science education at the conclusion of this science education course.

As a result of these findings, designing the learning environment for a future science pedagogy course will need to consider issues identified in this study. Implementing science education and understanding children's manipulative skill development will need to be more explicit within the course structure. For example, using effective questioning skills for teaching primary science may be analysed more closely using recognised teaching strategies such as Bloom's Taxonomy. In addition, explicit illustrations of teaching techniques such as modelling effective science classroom management and demonstrating methods for critically evaluating primary science teaching need to be incorporated more thoroughly into this tertiary curriculum. Learning designs for this course will also need to address the issue of a significant number of preservice teachers (i.e., 30\%) not understanding children's manipulative skills for investigating science education. These preservice teachers demonstrated science lessons to their peers which, consequently, may not facilitate an understanding of children's skill development. Arranging for large numbers of preservice teachers to teach in a primary setting within this course may prove problematic; however there may be opportunities to include understanding children's manipulative skills while they are completing a practicum.

Educators need to develop instruments to measure preservice teachers' primary science teacher development. Such instruments can be linked to reform agendas and course objectives (anticipated outcomes) to inform tertiary education practices. Indeed, education has become outcomes based in schools, which should also be developed in university settings. A pretest-posttest survey instrument (e.g., Appendix 1) that is linked to course outcomes and the literature may aid in assessing the pedagogical development of preservice primary teachers and their standard of preparation for the teaching profession. Information from a pretest can provide an understanding of the preservice teachers' prior knowledge, which may be used to redesign coursework at the beginning of a course to address possible needs. A posttest can be used to assess preservice teacher development as a result of engagement in a course and can provide further direction for enhancing tertiary education programs. Qualitative research (e.g., interviews, preservice teachers' assessment tasks) may also provide further understandings for designing more effective learning environments for preservice teachers involved in primary science education.

Educators need to be continually guided by the learning needs of preservice teachers and sequentially build upon the preservice teachers' prior knowledge for achieving the course objectives and reform agendas. Hence, instruments need to be developed to gather information on the needs of preservice teachers before commencing their course (e.g., science education unit) in order for educators to plan more appropriately, and to gather information at the conclusion of a course to determine the preparedness of preservice teachers to teach primary science in line with reform agendas. This information may also be used as an accountability indicator to preservice teachers, the teaching 
profession, the science community, and the government to inform the degree to which preservice teacher education programs are implementing reform agendas.

\section{References}

Abruscato, J. (2004). Teaching children science: A discovery approach. NY: Allyn \& Bacon.

Abell, S. K., \& Bryan, L. A. (1999). Development of professional knowledge in learning to teach elementary science. Journal of Research in Science Teaching, 36(2), 121-139.

American Association for the Advancement of Science. (1993). Benchmarks for science literacy: Project 2061. New York, NY: Oxford University Press.

Australian National Science Standard Committee (ANSCC) / Australian Science Teachers' Association (ASTA). (2002). National professional standards for highly accomplished teachers of science. Canberra, Australia: ASTA.

Biggs, J. (1999) Teaching for quality learning. Buckingham: Society for Research into Higher Education and Open University Press.

Board of Studies. (1999). Science and technology k-6: Outcomes and indicators. Sydney, NSW: New South Wales Department of Education and Training.

Briscoe, C., \& Peters, J. (1997). Teacher collaboration across and within schools: Supporting individual change in elementary science teaching. Science Teacher Education, 81(1), 5164.

Bybee, R. W. (1978). Science educators' perceptions of the ideal science teacher. School Science and Mathematics, 78(1), 13-22.

Bybee, R. W. (1997). Achieving scientific literacy. Portsmouth, NH: Heinemann.

Bybee, R. W., \& McInerney, J. D. (Eds.) (1995). Redesigning the science curriculum: A report on the implications of standards and benchmarks for science education. Colorado Springs, Colorado: Biological Sciences Curriculum Study.

Coates, D., Jarvis, T., McKeon, F., \& Vause, J. (1998). All together now: Science support for mentors and students. Primary Science Review, 55, 9-11.

Corcoran, E., \& Andrew, M. (1988). A full year internship: An example of school-university collaboration. Journal of Teacher Education, 39(3), 17-23.

Crowther, D. T., \& Cannon, J. R. (1998, January). How much is enough? Preparing elementary science teachers through science practicums. Paper presented at the annual meeting of the Association for the Education of Teachers of Science, Minneapolis, MN.

Feiman-Nemser, S., \& Parker, M. (1992). Mentoring in context: A comparison of two U.S. programs for beginning teachers. NCRTL Special Report. East Lansing, MI: National Center for Research on Teacher Learning.

Fleer, M., \& Hardy, T. (2001). Science for children. Sydney, Australia: Prentice Hall.

Gonzales, F., \& Sosa, A. (1993). How do we keep teachers in our classrooms? The TNT response. Idra Newsletter, 1, 6-9.

Goodrum, D., Hackling, M., \& Rennie, L. (2001). The status and quality of teaching and learning in Australian schools. Canberra, Australia: Department of Education, Training and Youth Affairs.

Gunstone, R. F., \& White, R. T. (1981). Understanding of gravity. Science Education, 65(3), 291299.

Harlen, W. (1999). Effective teaching of science. A review of research. Using Research Series, 21. Edinburgh, UK: Scottish Council for Research in Education.

Hittleman, D. R., \& Simon, A. J. (2002). Interpreting educational research: An introduction for consumers of research. New Jersey: Prentice-Hall.

Hudson, P. (2000). Integrating science, writing and art. Investigating: Australian Primary and Junior Science Journal, 16(1), 35-38. 
Hudson, P., \& Ginns, I. (2005, April). Assessing second-year preservice teachers' elementary science pedagogical knowledge. Paper presented at the National Association for Research in Science Teaching (NARST), Dallas, TX.

Hudson, P., \& McRobbie, C. (2004). Evaluating a specific mentoring intervention for preservice teachers of primary science. Action in Teacher Education, 17(2), 7-35.

Hudson, P., Skamp, K., \& Brooks, L. (2005, in press). Development of an instrument: Mentoring for effective primary science teaching (MEPST). Science Education.

Jarvis, T., McKeon, F., Coates, D., \& Vause J. (2001). Beyond generic mentoring: Helping trainee teachers to teach primary science. Research in Science and Technological Education, 19(1), 5-23.

Kline, R. B. (1998). Principles and practices of structural equation modeling. New York: The Guildford Press.

Lunetta, V. N., \& Lederman, N. G. (1998). Reform of science education in Taiwan: Contexts, opportunities, and concerns. Retrieved 10 June, 2005, from http://nr.stic.gov.tw/ejournal/ProceedingD/v8n3/121-131.pdf

Queensland School Curriculum Council. (1999). Science: Years 1-10 syllabus. Brisbane, QLD: QSA.

Rice, D. C., \& Roychoudhury, A. (2003). Preparing more confident preservice elementary science teachers: One elementary science methods teacher's self-study. Journal of Science Teacher Education, 14(2), 97-126.

Rosaen, C., \& Lindquist, B. (1992). Collaborative teaching and research: Asking 'What does it mean?' Elementary Subject Centre Series No.73. Michigan: Institute for research on Teaching, MSU.

Schön, D. (1987). Educating the reflective practitioner. San Francisco, CA: Jossey Bass.

Skamp, K. (Ed.). (2004). Teaching primary science constructively. Sydney, Australia: Harcourt Brace.

Sparrow, L., Sparrow, H., \& Swan, P. (2000, February). Student centred learning: Is it possible? In Proceedings of the 9th Annual Teaching and Learning Forum, Perth, Curtin University of Technology.

Tobin, K., \& Fraser, B. J. (1990). What does it mean to be an exemplary science teacher? Journal of Research in Science Teaching, 27(1), 3-25.

Watters, J. J., \& Ginns, I. S. (2000). Developing motivation to teach elementary science: Effect of collaborative and authentic learning practices in preservice education. Journal of Science Teacher Education, 11(4), 301-321.

Wandersee, J., Mintzes, J., \& Novak, J. (1994). Research on alternative conceptions in science. In D. Gabel (Ed.), Handbook of research on science teaching and learning (pp. 177-210). New York: MacMillan.

(c) Copyright Peter Hudson 2005.

Please cite as: Hudson, P. (2005). Informing future learning designs in preservice teacher education through quantitative research: a primary science example. Journal of Learning Design, 1(1), 33-44. www.jld.qut.edu.au/Vol 1 No 1 


\section{Primary Curriculum and Pedagogies: Science}

Appendix 1

SECTION 1: This section aims to find out some information about you in relation to your responses in Section 2. To preserve your anonymity, write your mother's maiden name on this survey. Please circle the answers that apply to you. Thank you for your participation.

\section{Mother's maiden name:}
a) What is your sex?
Male
Female
b) What is your age?
$<22$ yrs
$22-29$ yrs
$30-39$ yrs
$>40$ yrs
c) What science courses did you complete in Years 11 and 12 at high school?

d) How many science curriculum/methodology courses have you completed at university so far?

$$
\begin{array}{lllll}
0 & 1 & 2 & 3 & 4 \text { or more }
\end{array}
$$

e) How many block practicums (field experiences have you now completed during your tertiary $\begin{array}{lllllll}\text { teacher education? } & 0 & 1 & 2 & 3 & 4 & 5 \text { or more }\end{array}$

f) How many primary science lessons have you taught so far?

$\begin{array}{lllllll}0 & 1 & 2 & 3 & 4 & 5 & 6 \text { or more }\end{array}$

g) Would science be one of your strongest subjects?

Strongly disagree Disagree Uncertain Agree Strongly Agree

h) I would like to learn about teaching primary science in other educational systems?
Strongly disagree
Disagree
Uncertain
Agree
Strongly Agree

i) I would develop my primary science teaching by collaborating with university teacher education students from other countries?
Strongly disagree
Disagree
Uncertain
Agree
Strongly Agree

j) I believe I have the knowledge and skills in primary science teaching to interact effectively with university teacher education students from other countries?
Strongly disagree
Disagree
Uncertain
Agree
Strongly Agree 
SECTION 2:

The following statements relate to your development towards becoming a teacher of primary science. Please indicate the degree to which you disagree or agree with each statement below by circling only one response to the right of each statement.

Key

SD $=$ Strongly Disagree

D = Disagree

$\mathbf{U}=$ Uncertain

$\mathbf{A}=$ Agree

$\mathbf{S A}=$ Strongly Agree

In developing my understanding of primary curriculum and pedagogies towards becoming a teacher of primary science, I believe I can:

1. articulate the key components of the primary science syllabus. ............ SD $\quad$ D $\quad$ U $\quad$ A

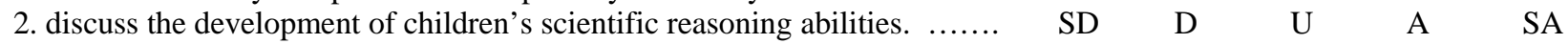

3. provide a rationale based on theory for designing and implementing an effective science program.

4. provide a problem-based learning environment for teaching primary science.

5. devise clear lesson structures for teaching primary science. ............... SD

6. discuss the development of children's attitudes for learning primary science. SD

7. develop a scope and sequence for teaching primary science. $\ldots \ldots \ldots \ldots \ldots$ SD

8. articulate the components of an effective primary science program. ........ SD

9. describe and analyse the theoretical base of science curriculum development. SD

D U A SA

10. use an outcomes-based approach for planning, implementing, and assessing primary science education.

11. implement appropriate primary science teaching strategies. ............. SD

12. articulate the affective domains for teaching and learning primary science. SD

13. model effective classroom management when teaching science. .......... SD

14. integrate primary science education with other key learning areas. ........ SD

15. articulate constructivist principles for teaching primary science. .......... SD

16. manage the primary science learning environment effectively. ........... SD

17. discuss the development of children's science concepts. ............... SD

18. compare existing approaches for teaching primary science. .............. SD

D U

D U

D $\quad$ U A

D $\quad$ U A

D $\quad$ U A

SA

SA

19. select appropriate activities and resources for teaching primary science. ... SD

D U A

20. address ethical and attitudinal issues related for implementing a primary science lesson.

21. design a primary science unit of work

SD D U A

D $\quad$ U A

SA

D $\quad$ U $\quad A-S A$

D U A $\quad$ SA

D U A

D U A

D U A

D U A

D U A

SA

SA

SA

SA

SA

SA

22. assess the students' learning of primary science. $\ldots \ldots \ldots \ldots \ldots \ldots \ldots \ldots \ldots$, SD

23. articulate different viewpoints on teaching primary science. ............. SD

24. critically reflect on becoming a more effective teacher of primary science. SD

25. use effective questioning skills for teaching primary science.

SD

D

D

SA

26. provide primary science lessons that cater for all students regardless of ability (i.e., inclusivity).

27. critically evaluate my primary science teaching.

SD D U

28. demonstrate an understanding of the development of children's manipulative skil

29. use concept maps for planning a primary science unit of work.

SD
SD
SD
SD
SD
SD
SD

$\mathrm{D}$

$\mathrm{D}$

A

SA

30. demonstrate positive attitudes towards teaching primary science.

$\begin{array}{lll}\text { D } & \text { U } & \text { A } \\ \text { D } & U & A \\ \text { D } & U & A \\ \text { D } & U & A \\ \text { D } & U & A \\ D & U & A \\ \text { D } & U & A\end{array}$

31. use hands-on materials for teaching primary science.

34. teach primary science confidently. SD

kills for investigating science. 